\title{
PENGARUH PROFESIONALISME DAN LOCUS OF CONTROL TERHADAP KINERJA AUDITOR PADA KANTOR AKUNTAN PUBLIK DI PEKANBARU RIAU
}

\author{
Sarmiati ${ }^{1}$, Badewin ${ }^{1}$, Rosliana ${ }^{1}$ \\ ${ }^{1}$ Prodi Akuntansi Fakultas Ekonomi dan Bisnis, Universitas Islam Indragiri \\ Email: badewin20@gmail.com (korespondensi)
}

\begin{abstract}
This study aims to test and obtain empirically the effect of professionalism and locus of control on the performance of auditors at a public accounting firm in Pekanbaru. The population in this study were auditors who worked at 9 KAPs in Pekanbaru. The method of determining the sample in this study was carried out using a convenience sampling technique. Respondents in this study found 60 auditors working at KAP Pekanbaru. The number of questionnaires distributed was 60 questionnaires. However, 42 questionnaires were returned and could be used for further analysis. The data analysis technique used is multiple linear regression analysis using SPSS 26.00 software. The data analysis model used is the validity and reliability test. The results showed that the variables of professionalism and locus of control contributed as much as 20.4 percent to the auditor's performance, the remaining 79.6 percent was influenced by other variables that were not included in the research model.
\end{abstract}

Keywords: Professionalism, Locus of control, Performance Auditor

\begin{abstract}
Abstrak
Penelitian ini bertujuan untuk menguji dan mendapatkan bukti empiris pengaruh profesionalisme dan locus of control terhadap kinerja auditor pada kantor akuntan publik di Pekanbaru. Populasi dalam penelitian ini adalah auditor yang bekerja pada 9 KAP di Pekanbaru. Metode penentuan sampel dalam penelitian ini dilakukan dengan menggunakan teknik convenience sampling. Responden dalam penelitian ini berjumlah 60 auditor yang bekerja di KAP Pekanbaru. Jumlah kuesioner yang disebar 60 kuesioner. Namun, yang kembali dan dapat digunakan untuk analisis lebih lanjut sebanyak 42 kuesioner. Teknik analisis data yang digunakan adalah analisis regresi linear berganda dengan menggunakan software SPSS 26.00. Model analisis data digunakan adalah uji validitas, dan reabilitas. Hasil penelitian menunjukan bahwa, variabel profesionalisme dan locus of control(Loc) berkontribusi sebanyak 20,4 persen pada Kinerja auditor sedangkan sisanya 79,6 persen dipengaruhi oleh variabel lain yang tidak dimasukan ke model penelitian.
\end{abstract}

Kata kunci: Profesionalisme, Locus of control, Kinerja Auditor

\section{PENDAhUlUan}

Persaingan antar perusahaan semakin meningkat, diiringi dengan berbagai masalah yang dihadapi oleh perusahaan di indonesia dalam menghadapi masalah para pengelola perusahaan membutuhkan jasa akuntan publik. Profesi akuntan publik telah menjadi sorotan masyarakat dalam beberapa tahun terakhir. Profesi akuntan publik dianggap penting bagi para pengguna laporan keuangan dikarenakan fungsinya yaitu untuk memberikan keyakinan yang memadai berkenaan dengan laporan keuangan yang disajikan oleh manajemen, melalui pendapat yang diberikan dalam laporan auditor. Terdapat lima jenis pendapat yang dapat diberikan oleh auditor, yaitu pendapat wajar tanpa pengecualian (unqualified opinion), pendapat wajar tanpa pengecualian dengan tambahan bahasa penjelas (unqualified opinion with explanatory language), pendapat wajar dengan pengecualian (qualified opinion), pendapat tidak wajar (adverse opinion), dan pernyataan tidak memberikan pendapat (disclaimer of opinion or no opinion). (Abdul Halim, 2015). 
Kasus skandal akuntansi mengenai audit mencerminkankan kinerja auditor yang kurang konsisten dan menimbulkan dampak yang kurang baik, sehingga dapat mempengaruhi kepercayaan masyarakat terhadap akuntan publik. Mengenai kasus Garuda, mengenai pembekuan izin audit laporan keuangan tahun 2019. Kasner dinilai melakukan pelanggaran berat yang berpotensi berpengaruh signifikan terhadap opini Laporan Auditor Independen (LAI). Kasner diduga melakukan tiga pelanggaran yaitu pertama, belum tepat menilai substansi transaksi untuk kegiatan perlakukan akuntansi terkait pengakuan piutang dan pendapatan lain-lain secara sekaligus, adanya kontrak piutang yang diakui sebagai pendapatan yang telah melanggar Standar Audit 315. Kedua, belum sepenuhnya mendapatkan bukti audit yang cukup dan tepat untuk menilai ketepatan perlakuan akuntansi sesuai subtansi transaksi dari perjanjian yang melandasi transaksi tersebut, hal ini melanggar Standar Audit 500. Ketiga yaitu sebagai akuntan publik ia belum mempertimbangkan adanya fakta-fakta setelah tanggal laporan keuangan, sebagai dasar untuk melakukan pertimbangan ketepatan perlakuan (https://www.merdeka.com/uang/sanksipembekuan-izin-akuntan-publik-auditorgaruda-indonesia-berlaku-27-juli-2019.html) Diakses pada 20 Januari 2021.

Abdul Halim (2015), Profesionalisme berarti suatu kemampuan yang dilandasi oleh tingkat pengetahuan yang tinggi dan pelatihan khusus, daya pemikiran yang kreatif untuk melaksanakan tugas-tugas yang sesuai dengan bidang keahlian dan profesinya. Seseorang dikatakan profesional jika memenuhi tiga kriteria, yaitu mempunyai keahlian untuk melaksanakan tugas sesuai dengan bidangnya, melaksanakan suatu tugas atau profesinya dengan menerapkan standar baku bidang profesi yang bersangkutan dan menjalankan tugas profesinya dengan mematuhi etika profesi yang telah ditetapkan. Seorang akuntan publik tercermin melalui hasil kinerja auditor dalam menjalankan tugas dan fungsinya sebagai profesional, auditor mengakui tanggung jawabnya terhadap masyarakat, terhadap klien, dan terhadap rekan seprofesi, termasuk dalam berperilaku.

Made Gheby dan Dewa Dharma (2015) variabel profesionalisme diukur dengan indikator pengabdian terhadap profesi, keyakinan terhadap peraturan profesi standar profesi, kewajiban sosial, kemandirian dan hubungan dengan rekan seprofesi/afiliasi. Kuesioner untuk variabel Profesionalisme menggunakan kuesioner yang telah dikembangkan oleh Baigi Rabbani Adha (2016). Menurut penelitian Made Gheby dan Dewa Gede Dharma (2015) secara parsial memperoleh Profesionalisme berpengaruh positif pada Kinerja auditor. Menurut Ida Bagus dan I Wayan (2015) variabel Profesionalisme berpengaruh positif terhadap Kinerja auditor.

Rotter (1966) Locus of control adalah tingkat sejauh mana seseorang mengharapkan bahwa penguatan atau hasil dari perilaku mereka tergantung pada penilaian mereka sendiri atau karakteristik pribadi. Locus of control adalah tingkat keyakinan seseorang atau individu terhadap sumber penyebab peristiwa-peristiwa yang terjadi dalam kehidupannya, apakah keberhasilan, prestasi dan kegagalan dalam hidupnya dikendalikan oleh perilakunya sendiri (faktor internal) atau semua peristiwa-peristiwa yang terjadi dalam hidupnya berupa prestasi, kegagalan dan keberhasilan dikendalikan oleh kekuatan lain, seperti pengaruh orang lain yang berkuasa, kesempatan, keberuntungan dan nasib (faktor eksternal). Locus of control merupakan salah satu faktor yang mempengaruhi kinerja auditor karena mereka bekerja dengan baik, mereka yakin bahwa hal tersebut disebabkan oleh usaha atau keterampilan mereka sendiri atau usaha masing-masing individu, mereka digolongkan sebagai internal (Ayudiati, 2011). Auditor yang mempunyai locus of control internal akan lebih mempunyai kontribusi positif pada kinerja melaksanakan tugas audit. Hal ini dikarenakan mereka memandang locus of control internal sebagai usaha yang harus dilakukan jika ingin berhasil sedangkan locus of control eksternal dilakukan pada orang yang kurang suka berusaha.

\section{TINJAUAN PUSTAKA}

\subsection{Auditing}

Definisi audit yang sangat terkenal berasal dari ASOBAC (A Statement of Basic Auditing Concepts) yang mendefinisikan auditing sebagai suatu proses sistematis untuk menghimpun dan mengevaluasi bukti-bukti secara objektif mengenai asersi-asersi tentang berbagai tindakan dan kejadian ekonomi untuk menentukan tingkat kesesuaian antara asersi-asersi tersebut dengan kriteria yang telah ditentukan dan menyampaikan hasilnya kepada para pemakai yang berkepentingan. 


\subsection{Standar Auditing}

Standar auditing yang ditetapkan Ikatan Akuntansi Indonesia (IAI) mengharuskan auditor menyatakan apakah menurut pendapatnya laporan keuangan yang di sajikan sesuai dengan prinsip akuntansi yang berlaku umum di indonesia, dan jika ada menunjukkan ketidakkonsistenan penerapan prinsip akuntansi dalam penyusunan laporan keuangan periode berjalan dibandingkan dengan penerapan prinsip akuntansi tersebut dalam periode sebelumnya.

\subsection{Auditor}

Secara umum menurut Abdul Halim (2015), mengklasifikasikan auditor menjadi tiga kelompok yaitu:

1. Auditor Internal

Auditor internal merupakan karyawan suatu perusahaan tempat mereka melakukan audit. Tujuan audit internal adalah untuk membantu manajemen dalam melaksanakan tanggungjawabanya secara efektif. Auditor internal terutama berhubungan dengan audit operasional dan audit kepatuhan. Meskipun demikian, pekerjaan auditor internal dapat mendukung audit atas laporan keuangan yang dilakukan auditor independen.

2. Auditor Pemerintah

Auditor pemerintah adalah auditor yang bekerja di instansi pemerintah yang tugas utamanya adalah melakukan audit atas pertanggungjawaban keuangan dari berbagai unit organisasi dalam pemerintahan. Auditing ini dilaksanakan oleh auditor pemerintah yang bekerja di BPKP, BPK dan juga auditor pemerintah yang bekerja di Direktorat Jenderal Pajak. Tugas auditor perpajakan ini adalah memeriksa pertanggungjawaban keuangan para wajib pajak baik perseorangan maupun yang berbentuk organisasi kepada pemerintah.

3. Auditor Independen (Akuntan Publik) Auditor independen adalah para praktisi individual atau anggota kantor akuntan publik yang memberikan jasa auditing profesional kepada klien. Klien berupa perusahaan bisnis yang berorientasi laba, organisasi nirlaba, badan-badan pemerintah, maupun individu perseorangan.

\subsection{Profesionalisme}

Pengertian umum, seseorang dikatakan profesional jika memenuhi tiga kriteria, yaitu mempunyai keahlian untuk melaksanakan tugas sesuai dengan bidangnya, melaksanakan suatu tugas atau profesi dengan menetapkan standar baku di bidang profesi yang bersangkutan dan menjalankan tugas profesinya dengan mematuhi etika profesi yang telah ditetapkan. Profesi dan profesionalisme dapat dibedakan secara konseptual (Lekatompessy, 2003).

\subsection{Locus of control}

Menurut Rotter (1966) menjelaskan bahwa locus of control adalah tingkat sejauh mana seseorang mengharapkan bahwa penguatan atau hasil dari perilaku mereka tergantung pada penilaian mereka sendiri atau karakteristik pribadi. Locus of control merupakan salah satu faktor yang mempengaruhi kinerja auditor karena mereka bekerja dengan baik, mereka yakin bahwa hal tersebut disebabkan oleh usaha atau keterampilan mereka sendiri atau usaha masing-masing individu mereka digolongkan sebagai internal (Ayudiati, 2011). Auditor yang mempunyai locus of control internal akan lebih mempunyai kontribusi positif pada kinerja melaksanakan tugas audit. Hal ini dikarenakan mereka memandang locus of control internal sebagai usaha yang harus dilakukan jika ingin berhasil sedangkan locus of control eksternal dilakukan pada orang yang kurang suka berusaha.

\subsection{Kinerja Auditor}

Menurut Mulyadi (2016) Kinerja auditor adalah akuntan publik yang melaksanakan penugasan pemeriksaan (examination) secara objektif atas laporan keuangan suatu perusahaan organisasi lain, dengan tujuan untuk menentukan apakah laporan keuangan tersebut menyajikan secara wajar sesuai dengan prinsip akuntansi yang berlaku umum, dalam semua hal yang material, posisi keuangan, dan hasil usaha perusahaan. Kinerja audior merupakan tindakan atau pelaksanaan tugas pemeriksaan yang telah diselesaikan oleh auditor dalam kurun waktu tertentu. Kinerja (prestasi kerja) dapat diukur melalui pengukuran tertentu (standar), kualitas berkaitan dengan mutu kerja yang dihasilkan, kuantitas adalah jumlah hasil kerja yang dihasilkan dalam kurun waktu tertentu, dan ketetapan waktu adalah kesesuaian waktu yang telah direncanakan (Trisnaningsih, 2007).

\subsection{Kerangka Pemikiran}

Menurut Mulyadi (2016), Kinerja auditor adalah auditor yang melaksanakan penugasan pemeriksaan (examination) 
secara objektif atas laporan keuangan suatu perusahaan atau organisasi lain dengan tujuan untuk menentukan apakah laporan keuangan tersebut menyajikan secara wajar sesuai dengan prinsip akutansi yang berlaku umum, dalam semua hal yang material, posisi keuangan dan hasil usaha perusahaan.

Profesionalisme merupakan sifat utama yang harus dimiliki oleh seorang auditor. Profesionalisme auditor yang tinggi akan berpengaruh pada kinerja auditor yang baik pula dalam melakukan pekerjaannya. Profesionalisme dari seorang akuntan publik tercermin melalui hasil kinerja auditor dalam menjalankan tugas dan fungsinya.

Auditor dengan locus of control internal akan mempunyai kontribusi positif pada kinerja melaksanakan tugas audit, oleh karena itu mereka memandang locus of control internal sebagai usaha yang harus dilakukan jika ingin berhasil sedangkan locus of control eksternal dilakukan pada orang yang kurang suka berusaha. Locus of control eksternal disebabkan oleh faktor luar yang mengontrol dan sedikit korelasi antara usaha dengan kesuksesan. Berdasarkan uraian diatas, penulis merumuskan kerangka pemikiran sebagai berikut:
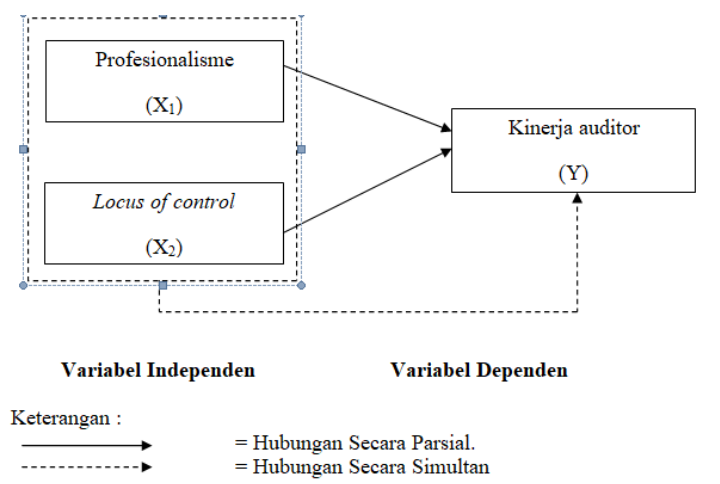

Gambar 1. Kerangka Pemikiran

\subsection{Hipotesa}

$\mathrm{H}_{1}$ : Profesionalisme

berpengaruh terhadap kinerja auditor pada kantor akuntan publik di Pekanbaru

$\mathrm{H}_{2}$ : Locus of control berpengaruh terhadap kinerja auditor Pada kantor akuntan publik di Pekanbaru.

$\mathrm{H}_{3}$ : Profesionalisme dan locus of control berpengaruh secara simultan terhadap kinerja auditor pada kantor akuntan publik di Pekanbaru.

\section{METODOLOGI PENELITIAN}

\subsection{Rancangan Penelitian}

Rancangan penelitian ini adalah penelitian kausal komperatif (causal comperative research). Penelitian kausal komperatif merupakan tipe penelitian dengan karakteristik masalah berupa hubungan sebab akibat antara dua variabel atau lebih (Indriantoro dan Supomo, 2016).

\subsection{Tempat dan Waktu Penelitian}

Penelitian ini dilakukan pada kantor akuntan publik di Kota Pekanbaru Provinsi Riau. Jenis metode penelitian yang digunakan berupa cross section data penelitian yang dilakukan sekali selesai, sehingga tidak ada kelanjutannya (Sugiyono, 2018). Penelitian ini diambil dalam kurun waktu tertentu selama kurang lebih 3 bulan. Waktu penelitian tersebut dihitung dari Februari sampai April 2021 yang mulai dari tahap survei tempat penelitian, proses perizinan dan pengolahan data.

\subsection{Populasi dan Sampel}

Menurut Sugiyono (2018), populasi dapat diartikan sebagai wilayah generalisasi yang terdiri atas obyek/subjek yang mempunyai kuantitas dan karakteristik tertentu yang ditetapkan oleh peneliti untuk dipelajari dan kemudian ditarik kesimpulannya. Populasi dalam penelitian ini adalah seluruh pegawai yang bekerja di kantor akuntan publik di Pekanbaru. Sampel adalah bagian dari jumlah dan karakteristik yang dimilki oleh populasi tersebut, (Indriantoro dan Supomo, 2016). Sampel dari penelitian ini berjumlah 42 responden yang bekerja di kantor akuntan publik di Pekanbaru. Metode pemilihan sampel yang digunakan adalah convenience sampling. Convenience sampling merupakan tehnik dalam memilih sampel, peneliti tidak mempunyai pertimbangan lain hanya berdasarkan kemudahan saja (Indriantoro dan Supomo, 2016). Dimana elemen populasi yang dipilih subyek sampel adalah tidak terbatas sehingga peneliti memiliki kebebasan untuk memilih sampel yang paling cepat dan mudah.

\subsection{Prodesur Pengumpulan Data}

Jenis data yang digunakan dalam penelitian ini yaitu data primer. Data primer adalah data yang di peroleh secara langsung dari jawaban kuesioner dari reponden yang di kirim secara langsung kepada auditor (Indriantoro dan Supomo, 2016). Peneliti mengumpulkan data primer yang diperoleh dari penyebaran kuesioner langsung kepada responden yaitu auditor di kantor akuntan publik di Pekanbaru yang menjadi sampel. Pengukuran setiap responden diminta 
pendapat mengenai suatu pernyataan dengan skala penilaian dari 1 sampai 5 . Skala pengukuran yang digunakan dalam penelitian ini adalah skala likert. Skala likert merupakan metode yang mengukur sikap dengan menyatakan setuju atau ketidaksetujuan terhadap subjek, obyek atau kejadian tertentu (Indriantoro dan Supomo, 2016).

\subsection{Teknik Analisa Data}

Sesuai dengan rumusan masalah, tujuan penelitian dan hipotesis, maka penelitian ini menggunakan metode regresi linier berganda antara variabel dependen dalam hal ini adalah kinerja auditor dan variabel independen yaitu profesionalisme dan locus of control.

\section{HASIL DAN PEMBAHASAN}

\subsection{Uji Statistik Deskriptif}

Uji statistik deskriptif digunakan untuk memberikan gambarkan secara umum mengenai semua variabel yang digunakan dalam penelitian ini yaitu variabel profesionalisme, locus of control dan kinerja auditor, dengan cara melihat tabel statistik deskriptif yang menunjukkan data yang digunakan. Berikut ini adalah rangkuman hasil uji statistik deskriptif.

Tabel 1. Statistik Deskriktif

\begin{tabular}{l|rrrrrrr}
\multicolumn{9}{c}{ Descriptive Statistics } \\
& N & Minimum & Maximum & \multicolumn{2}{c}{ Mean } & \multicolumn{2}{c}{ Std. Deviation } \\
& Statistic & Statistic & Statistic & Statistic & Std. Error & Statistic \\
\hline PROFESIONALISME & 42 & 56 & 70 & 64.48 & .574 & 3.717 \\
\hline LOCUS OF CONTROL & 42 & 16 & 43 & 28.21 & .763 & 4.946 \\
\hline KINERJA AUDITOR & 42 & 31 & 44 & 40.07 & .456 & 2.958 \\
\hline ValidN (istwise) & 42 & & & & & \\
\hline
\end{tabular}

Sumber: Data Olahan SPSS 26, 2021

Pada tabel 1 diketahui bahwa jumlah responden $(\mathrm{N})$ yang diolah pada penelitian ini berjumlah 42 responden. Pada variabel (X1) Profesionalisme terdiri dari 14 pertanyaan. Responden memiliki jawaban yang bervariasi dengan nilai minimal jawaban adalah 57 dan nilai maksimal adalah 68 dengan rata-rata jawaban 64,48 serta standar deviasi 3,717. Variabel (X2) Locus of control terdiri dengan 10 pertanyaan dan memiliki nilai jawaban minimal adalah 16 dan maksimal 43 dengan rata-rata jawaban 28,21 serta dengan standar deviasi 4,946. Variabel (Y) Kinerja Auditor terdiri dari 9 pertanyaan dan memiliki nilai jawaban minimal adalah 31 dan maksimal 44 dengan rata-rata jawaban 40,07 serta dengan standar deviasi 2,958.

\subsection{Uji Validitas}

Uji validitas digunakan untuk mengukur sah atau valid tidaknya suatu kuesioner dengan membandingkan, nilai $r$ hitung dengan $r$ tabel untuk degree of freedom (df). Dimana rumus untuk mencari degree of freedom (df) adalah, banyaknya sampel penelitian (N) dikurangi banyaknya variabel bebas dan terikat (k). Df $=\mathrm{n}-\mathrm{k}=42-2-1=39$, Berdasarkan tabel $r$ product moment diperoleh nilai $r$ tabel sebesar 0,308. Suatu kuesioner dikatakan valid apabila $r$ hitung $>r$ tabel (Ghozali, 2016). Hasil pengujian validitas untuk variabel profesionalisme ditunjukkan dalam tabel berikut:

Tabel 2. Hasil Uji Validasi Variabel Profesionalisme $\left(\mathrm{X}_{1}\right)$

\begin{tabular}{|c|c|c|c|}
\hline $\begin{array}{c}\text { Item } \\
\text { pertanyaan ke }\end{array}$ & $\mathbf{r}$ Hitung & $\mathbf{r}$ Tabel & Keterangan \\
\hline 1 & 0,455 & 0,308 & Valid \\
\hline 2 & 0,455 & 0,308 & Valid \\
\hline 3 & 0,491 & 0,308 & Valid \\
\hline 4 & 0.523 & 0,308 & Valid \\
\hline 5 & 0.601 & 0,308 & Valid \\
\hline 6 & 0,601 & 0,308 & Valid \\
\hline 7 & 0,476 & 0,308 & Valid \\
\hline 8 & 0,491 & 0,308 & Valid \\
\hline 9 & 0,718 & 0,308 & Valid \\
\hline 10 & 0,342 & 0,308 & Valid \\
\hline 11 & 0,310 & 0,308 & Valid \\
\hline 12 & 0,434 & 0,308 & Valid \\
\hline 13 & 0,718 & 0,308 & Valid \\
\hline 14 & 0,519 & 0,308 & Valid \\
\hline \multicolumn{2}{|l}{ Sumber: Data Olahan SPSS 26,2021} & & \\
\hline
\end{tabular}

Tabel 3. Hasil Uji Validasi Variabel Locus of Control $\left(\mathrm{X}_{2}\right)$

\begin{tabular}{|c|c|c|c|}
\hline $\begin{array}{c}\text { Item } \\
\text { pertanyaan ke }\end{array}$ & $\mathbf{r}$ Hitung & $\mathbf{r}$ Tabel & Keterangan \\
\hline 1 & 0,529 & 0,308 & Valid \\
\hline 2 & 0,415 & 0,308 & Valid \\
\hline 3 & 0,480 & 0,308 & Valid \\
\hline 4 & 0,655 & 0,308 & Valid \\
\hline 5 & 0,742 & 0,308 & Valid \\
\hline 6 & 0,665 & 0,308 & Valid \\
\hline 7 & 0,625 & 0,308 & Valid \\
\hline 8 & 0,677 & 0,308 & Valid \\
\hline 9 & 0,543 & 0,308 & Valid \\
\hline 10 & 0,375 & 0,308 & Valid \\
\hline \multicolumn{2}{|c|}{ Sumber: Data Olahan SPSS 26,2021 } \\
\hline
\end{tabular}

Tabel 4. Hasil Uji Validasi Variabel Kinerja Auditor (Y)

\begin{tabular}{|c|c|c|c|}
\hline $\begin{array}{c}\text { Item } \\
\text { pertanyaan ke }\end{array}$ & r Hitung & r Tabel & Ket \\
\hline 1 & 0,350 & 0,308 & Valid \\
\hline 2 & 0,559 & 0,308 & Valid \\
\hline 3 & 0,448 & 0,308 & Valid \\
\hline 4 & 0,649 & 0,308 & Valid \\
\hline 5 & 0,613 & 0,308 & Valid \\
\hline 6 & 0,498 & 0,308 & Valid \\
\hline 7 & 0,641 & 0,308 & Valid \\
\hline 8 & 0,469 & 0,308 & Valid \\
\hline 9 & 0,309 & 0,308 & Valid \\
\hline
\end{tabular}

Berdasarkan hasil uji validitas seluruh pertanyaan variabel penelitian menunjukan bahwa nilai kolerasi tiap item pertanyaan 
total skor yang diperoleh lebih besar dari 0,308 sehingga dapat disimpulkan bahwa item pertanyaan yang digunakan adalah valid dan dapat digunakan dalam analisis selanjutnya.

\section{KESIMPULAN DAN SARAN}

Penelitian ini bertujuan untuk menganalisis pengaruh profesionalisme dan locus of control terhadap kinerja auditor pada kantor akuntan publik di Pekanbaru. Untuk menganalisis hubungan antar variabel tersebut di perlukan SPSS 26 untuk mengolah data. Berdasarkan data yang telah dikumpulkan dan pengujian yang telah dilakukan maka dapat diperoleh kesimpulan sebagai berikut:

1. Profesionalisme diketahui memiliki $t_{\text {hitung }}$ sebesar 3,041 sedangkan tabel sebesar 2,022 sehingga $t_{\text {hitung }}>t_{\text {tabel }}$ dengan signifikan untuk variabel Profesionalisme lebih kecil 0,004 dari pada taraf signifikan 0,05 maka $\mathrm{H}_{1}$ diterima sehingga dapat disimpulkan bahwa profesionalisme berpengaruh terhadap kinerja auditor, semakin tinggi profesionalisme, maka dapat memengaruhi kinerja auditor yang semakin tinggi dalam menyelesaikan tugas-tugasnya. Apabila seorang auditor memiliki tingkat profesionalisme yang tinggi dalam menyelesaikan suatu tugas, maka akan berdampak pada meningkatnya kinerja auditor, karena auditor yang profesional harus memiliki rasa tanggungjawab, jujur, dan ahli dalam melaksanakan tugasnya.

2. Locus of control diketahui memiliki thitung sebesar $-1,685$ sedangkan tabel sebesar 2,022 sehingga $t_{\text {hitung }}<t_{\text {tabel }}$ dengan signifikan untuk variabel locus of control lebih besar 3,041 dari pada taraf signifikan 0,05 maka $\mathrm{H}_{2}$ ditolak sehingga dapat disimpulkan bahwa locus of control tidak berpengaruh terhadap kinerja auditor. Semakin tinggi locus of control eksternal akan memengaruhi kinerja auditor yang dapat mengalami penurunan dalam menyelesaikan tugastugasnya. Locus of control eksternal akan merasa lebih mudah terancam dan tidak berdaya, sehingga strategi yang dipilih lebih condong reaktif. Apabila seorang auditor lebih mempercayai nasib daripada kemampuan yang dimiliki, maka hal tersebut akan mempengaruhi kinerja auditor tersebut yang dapat mengalami penurunan, sedangkan Locus of control internal semakin tinggi locus of control internal, maka akan memengaruhi kinerja auditor yang semakin tinggi dalam menyelesaikan tugas-tugasnya. Locus of control internal berkaitan pada peningkatan kinerja. Apabila seorang auditor memiliki kemampuan, serta minat dan bakat yang tinggi dari dalam dirinya maka hal tersebut akan memacu kepercayaan dirinya dalam meningkatkan kinerjanya.

3. Uji secara simultan bahwa variabel profesionalisme dan locus of control menunjukan bahwa $F_{\text {hitung }}$ sebesar 6,269 lebih besar dari $F_{\text {tabel }}$ sebesar 3,24 dengan $\mathrm{df}$ pembilang $=2$, df penyebut $=$ 39 dan taraf signifikan $a=0,05$ sehingga Profesionalisme dan Locus of control secara bersama-sama berpengaruh signifikan terhadap Kinerja auditor pada Kantor Akuntan Publik (KAP) di Pekanbaru, sehingga $\mathrm{H} 3$ diterima. Artinya apabila diuji secara bersamasama maka variabel profesionalisme dan locus of control berpengaruh secara signifikan terhadap Kinerja auditor. Hasil penelitian ini dapat dilihat bahwa sikap profesionalisme dan diimbangi dengan locus of control yang tinggi akan memberikan kontribusi yang baik pula terhadap kinerja auditor yang dihasilkan.

4. Uji koefisien determinasi (Adjusted $R$ Square) sebesar 0,204. Artinya adalah bahwa pengaruh variabel profesionalisme dan locus of control terhadap kinerja auditor sebesar 20,4\% sedangkan sisanya $79,6 \%$ dipengaruhi oleh variabel lain yang tidak dimasukan dalam model penelitian ini.

\section{DAFTAR PUSTAKA}

[1] Arens, Alvin A, dkk. 2017. Auditing and Assurance Service an Integrated Approach. 16th Edition. Pearson Education.Amerika Serikat.

[2] Halim, Abdul. 2015. Auditing 1 (Dasar-dasar Audit Laporan Keuangan) Buku 1 Edisi 5. Penerbit Unit Penerbit dan Percetakan Sekolah Tinggi Ilmu Manajemen YKPN. Yogyakarta.

[3] Ikatan Akuntan Indonesia. 2001. Standar Profesional Akuntan Publik. Salemba Empat, Jakarta.

[4] Institut Akuntan Republik Indonesia. "Standar Profesional Akuntan Publik Per 31 Maret 2011. Edisi Revisi, Salemba empat : Jakarta

[5] Indriantoro, Nur dan Bambang Supomo. 2016. Metodologi Penelitian Bisnis. Edisi Pertama. Cetakan Ketujuh. Penerbit BPFE. Yogyakarta. 
[6] Lekatompessy, J.E. 2003. Hubungan profesionalisme dengan konsekuensinya komitemen organisasi, kepuasan kerja, prestasi kerja, dan keinginan berpindah. Studi Empiris di lingkungan Akuntan Publik. Jurnal Bisnis dan Akuntansi 5 (11), Hal 69-84.

[7] Mulyadi. 2013. Auditing Buku 1 Edisi 6. Penerbit Salemba Empat. Jakarta

[8] Rotter, JB. 1966. Generalized Expectancies for Internal Versus External Control of Reinforcement, PsychologicL Monographs, 80, 1-28.

[9] Sugiyono. 2018. Metode Penelitian Bisnis. Penerbit Alfabeta. Bandung

[10] Trisnaningsih, Sri. 2007. Independensi Auditor Dan Komitmen Organisasi Sebagai Mediasi Pengaruh Pemahaman Good Governence, Gaya Kepemimpinan dan Budaya Organisasi Terhadap Kinerja Auditor, Unhas Makassar, 26-28 Juli 2007. Universitas Pembangunan Nasional "Veteran", JawaTimur.

[11] Pertimbangkan fakta-fakta setelah tanggal laporan keuangan, dasar melakukan pertimbangan ketepatan perlakuan

.(https://www.merdeka.com/uang/s anksi-pembekuan-izin-akuntanpublik-auditor-garuda-indonesiaberlaku-27-juli-2019.html) Diakses pada 20 Januari 2021. 